\title{
Intestinal Integrity and Performance of Broiler Chickens Fed A Probiotic, A Prebiotic, or an Organic Acid
}

http://dx.doi.org/10.1590/1516-635x1604417-424

-Author(s)
Fernandes BCS'
Martins MRFB"
Mendes AA'
Milbradt EL'I'
Sanfelice $C^{\prime}$
Martins BB'
Aguiar EF'
Bresne $C^{\prime}$

Department of Animal Production, School of Veterinary Medicine and Animal Science, São Paulo State University, Botucatu - Brazil. " Department of Anatomy, Biosciences Institute, São Paulo State University, Botucatu - Brazil

III Department of Veterinary Clinical, School of Veterinary Medicine and Animal Science, São Paulo State University, Botucatu - Brazil.

\section{-Mail Address}

Corresponding author e-mail address Bárbara CS Fernandes

Department of Animal Production, School of Veterinary Medicine and Animal Science, São Paulo State University, Botucatu Brazil.

E-mail: barbarafernandes_zootecnista@ yahoo.com.br

\section{nKeywords}

Scanning electron microscopy, morphometrics, intestinal mucosa, intestinal wall.

\section{ABSTRACT}

This study aimed at evaluating the intestinal integrity, using light and scanning electron microscopy (SEM), and the performance of broiler chickens fed additives alternative to antimicrobials. A total of 1080 male chicks were distributed according to a completely randomized experimental design, with six treatments with six replicates of 30 birds each. The following treatments were evaluated: basal diet (control), basal diet supplemented with an antimicrobial, basal diet supplemented with a probiotic, basal diet supplemented with a prebiotic, basal diet with a symbiotic, and basal diet supplemented with organic acids. Weight gain, feed intake, feed conversion ratio and livability were recorded when broiler chickens were 10,21, 35, and 42 days old. On day 42, 72 birds were individually weighed and sacrificed. In order to evaluate the morphometrics of the different intestinal wall layers, segments of the small intestine and the cecum were collected from two birds per replicate, and intestinal integrity (SEM) was evaluated in the same segments of two birds per treatment. During the starter period (1-21 days old), birds fed the alternative additives presented similar weight gain as those fed the antimicrobial product, but were not different from control birds. Feed conversion ratio of birds fed alternative additives was better than that of the control birds from one to 10 days of age, but not during the remaining rearing period, and was similar to the birds receiving the antimicrobial. The morphometric parameters of the different intestinal wall layers was not influenced by the treatments. During the total rearing period, the evaluated alternative additives did not improve intestinal integrity or broiler performance.

\section{INTRODUCTION}

The maintenance of the integrity of the gastrointestinal tract (GIT) is essential for good animal productivity. The GIT absorbs nutrients more efficiently and limits the adhesion and replication of pathogens on the intestinal wall when the GIT is balanced and intact. It prevents enteric diseases, and consequently improves animal performance and reduced the mortality and the contamination of animal products (Edens, 2003).

Antimicrobial additives are used to control agents that may damage intestinal integrity, thereby significantly improving animal performance. However, the European Union banned the use of all antimicrobial growth promoters in livestock production in 2006, claiming that their residues in animal products place human health at risk due to the possible induction of bacterial resistance. Since then, several natural alternatives to antimicrobials have been researched. These alternatives include probiotics, prebiotics, symbiotics, organic acids, etc.

According to Silva \& Nörnberg (2003) and Santos \& Turnes (2005), probiotics and prebiotics may provide beneficial modulation of the 
intestinal microbiota, enhance the immune response, protect intestinal integrity, and consequently, the performance of poultry.

The benefits of the use organic acids in animal feeding may be explained by several mechanisms, including $\mathrm{pH}$ reduction, bacteriostatic properties, and metabolic effects of the anionic portion of the acids after their dissociation (Bellaver \& Scheuermann, 2004). These properties may potentially improve broiler intestinal integrity and performance.

There are many studies published in literature on the use of these alternative feed additives (Pelicano et al., 2007; Panda et al., 2009); however, performance and intestinal morphology results in broilers are still contradictory. Moreover, there are few studies in literature on the effect of these additives on intestinal ultrastructure. Therefore, the modes of action and the effects of these technologies need to be further studied.

The objective of this study were to evaluate the performance and the intestinal integrity, using light and scanning electron microscopy, of broiler chickens fed diets supplemented with probiotics, prebiotics, symbiotics, and organic acids.

\section{MATERIAL AND METHODS}

\section{Animals and experimental design}

The experiment was carried out in the experimental poultry house of School of Veterinary Medicine and Animal Science - São Paulo State University - Botucatu, Brazil (FMVZ-UNESP). In total, 1080 one-day-old male Cobb broiler chickens were housed at a density of 12 birds $/ \mathrm{m}^{2}$, according to a completely randomized experimental design including six treatments with six replicates of 30 birds each. The following treatments were applied: T1 - control: basal diet (no addition of antimicrobials or alternative additives), T2 - basal diet supplemented with an antimicrobial (enramycin), T3 basal diet supplemented with a probiotic, T4 - basal diet supplemented with a prebiotic, T5 - basal diet with a symbiotic $(\mathrm{T} 3+\mathrm{T} 4)$, and $\mathrm{T} 6$ - and basal diet supplemented with organic acids.

Birds were reared according to the conventional production system used in commercial broiler farms. The experimental poultry house were equipped with bell drinkers and tube feeders. Brooding heating was provided by $250 \mathrm{~W}$ electric infrared lamps. A $24 \mathrm{~h}$ of light lighting program was applied during the entire rearing period. Reused wood-shavings litter from a commercial broiler flock was used to promote health challenge. Birds were vaccinated against coccidiosis via drinking water, according to the manufacturer's recommendations, on the second day of life. No anticoccidial product was added to the feed.

The feeding program included four phases: prestarter (1-10 days of age), starter (11-21 days of age), grower (22-35 days of age), and finisher (36-42 days of age). Feed and water were supplied ad libitum during the entire rearing period.

The probiotic product contained $10^{7} \mathrm{CFU}$ of anaerobic bacteria/g, $10^{5}$ CFU of lactose-fermenting enterobacteria/g, $10^{6} \mathrm{CFU}$ of Enterococcus spp/g, and $10^{7} \mathrm{CFU}$ of Lactobacillus acidophilus/g, and was supplemented at $150 \mathrm{~g} /$ ton of pre-starter feed and at $100 \mathrm{~g} / \mathrm{ton}$ of the remaining feeds. The prebiotic product consisted of a mannan oligosaccharide (MOS) derived from the cell wall of the yeast Saccharomyces cerevisiae, and was added to the pre-starter diet at $1 \mathrm{~kg} / \mathrm{ton}$ and at $500 \mathrm{~g} / \mathrm{ton}$ of the remaining feeds. The symbiotic treatment consisted of the sum of the probiotic and prebiotic products used in the other treatments, which were added at the same levels described above. The organic acid product consisted of organic acids microencapsulated by vegetable fat, and included fumaric acid (64.1\%), calcium propionate $(10.3 \%)$, calcium formate $(20.5 \%)$, and potassium sorbate $(5.1 \%)$, and was added at $600 \mathrm{~g} / \mathrm{ton}$ diet at all feeding phases. The antimicrobial product (positive control) was enramycin (Enradin $®$ F80), registered at the Brazilian Ministry of Agriculture as an antimicrobial growth promoter, and was added at 10 ppm (125 g/ ton feed) during the pre-starter phase and at 5 ppm (63 $\mathrm{g} /$ ton de feed) during the starter, grower, and finisher phases. The basal diet was formulated according to the recommendations of Rostagno et al. (2005), as shown in Table 1. Treatments were established by the replacement of inert material (kaolin) by an equivalent amount of the studied products.

\section{Intestinal morphometrics}

At 42 days of age 72 birds (two per replicate of each treatment) were transported after six hours fasting in adequate crates to the experimental processing plant of FMVZ/UNESP, where they were individually weighed, electrically stunned, and sacrificed by cutting the jugular vein and carotid artery.

The gastrointestinal tract was removed, and the entire intestine and its segments (duodenum, jejunum, ileum, colon and cecum) were weighed in semi-analytical scales and measured with the aid of a measuring tape. 
The intestinal mucosa was histologically analyzed at the anatomy laboratory of the Biosciences Institute of São Paulo State University, Botucatu, Brazil. Approximately 2 $\mathrm{cm}$ of each intestinal segment were collected from two birds per replicate as follows: duodenum, from the pylorus to the distal portion of the duodenum loop; jejunum, from the distal portion of the duodenum loop to Meckel's diverticulum; ileum, from Meckel's diverticulum to cecum openings; and the right cecum.

Intestinal segments were opened through the mesenteric border and washed with distilled water, fixed in polypropylene plates, and immersed in buffered formalin solution at $10 \%$ for $24 \mathrm{~h}$, followed after routine light microscopy.

Tissue cuts were stained by Masson's trichrome stain, according to the method recommended by Behmer et al. (2003). Then, morphometric analysis of the following intestinal layers was carried out: mucosa, submucosa, and internal circular and external longitudinal muscle layers, which were analyzed with the aid of a light microscope coupled to an image analysis and processing software (Leica Qwin 3.0). Ten measurements per layer were performed.

The integrity of the intestinal mucosa was analyzed using scanning electron microscopy at the electronic microscopy laboratory of the Biosciences Institute of São Paulo State University, Botucatu, Brazil. Samples of different intestinal segments (duodenum, jejunum, ileum, and cecum) from two birds per treatment were collected, longitudinally opened, stretched, and briefly washed in $0.1 \mathrm{M}$ phosphate buffer $(\mathrm{pH} 7.3)$ to remove the intestinal content. Segments were fixed for $24 \mathrm{~h}$ at $4^{\circ} \mathrm{C}$ in glutaraldehyde at $2.5 \%$ in phosphate buffer at $0.1 \mathrm{M} \mathrm{(pH} \mathrm{7.3),} \mathrm{followed} \mathrm{after} \mathrm{routine} \mathrm{scanning}$ electron microscopy. After processing, samples were photographed using a scanning electron microscope (Quanta 200, FEl) at 10-15 kV tension. Images were analyzed for intestinal mucosa integrity considering epithelial loss, mucus presence, and villi organization.

\section{Performance parameters}

In order to evaluate performance parameters (weight gain, feed intake, feed conversion ratio and livability), feed intake was recorded and birds were weighed on the first and last day of each phase, that is, on days 1 and 10, 11 and 21, 22 and 35, and 36 and 42. Mortality was daily recorded to determine actual feed intake.

Feed intake was calculated as the difference between the weight of feed offered and the weight of feed residues at the end of each phase. Weight gain was calculated as the difference between final and initial weight in each phase. Feed conversion ratio was determined as the ratio between feed intake and weight gain at the end of each phase, corrected for the weight of dead birds during each phase.

Livability and production efficiency index (PEI) were also calculated. The equation used to calculate PEI was:

[(average daily weight gain in $\mathrm{g} x$ livability in \%) / feed conversion ratio]/10. 
Data were submitted to analysis of variance (ANOVA) using the General Linear Models procedure of the software program Statistical Analysis System (version 8.2). When significant, means were compared by the test of Tukey at $5 \%$ probability level or by the test of Duncan at 5\% probability level.

\section{RESULTS AND DISCUSSION}

During the pre-starter period (1-10 days) and the period of 1-21 days, the chickens of the control group presented lower $(p<0.05)$ weight gain $(W G)$ than those of the group fed the antimicrobial product, suggesting that the reused litter effectively represented a health challenge. On the other hand, the WG of birds supplemented with the alternative additives (probiotic, prebiotic, symbiotic, and organic acids) was not different from the antimicrobial group or from the control group, except for the symbiotic group, which presented higher WG compared with the control group during the pre-starter period (Table 2).

Similar results were obtained by Albino et al. (2006), who showed higher WG when broiler chickens were fed the antimicrobial avilamycin from one to 21 days of age relative to the control birds. However, the authors did not observed any WG differences when birds were fed graded concentrations of a prebiotic based on mannan oligosaccharides compared with those receiving or not avilamycin. On the other hand, opposite results were obtained by Godoi et al. (2008) and Viola et al. (2008), who observed WG differences among birds fed prebiotic/symbiotic and organic acids, respectively, relative to control birds during the period of one to 21 days.

There was no influence of the treatments on broiler weight gain during the periods of $1-35$ or 1-42 days of age. Oliveira et al. (2009), Appelt et al. (2010), and Khosravi et al. (2010) in experiments using a probiotic, a prebiotic, and an organic acid, respectively, also did not show any WG differences during the period of 1-42 days. Godoi et al. (2008), Salazar et al. (2008), and Meurer et al. (2010) observed higher WG in broiler chickens fed prebiotic/symbiotic, organic acids, and probiotic, respectively, compared with controls, considering the period between one and 42 days of age.

Feed intake $(\mathrm{Fl})$ was influenced $(p<0.05)$ by the treatments during the periods of 1-21 and 1-35 days of age. During the period of 1-21 days, broiler chickens fed alternative additives presented similar FI as to those in the antimicrobial group, but were not different from the controls, except for the prebiotic (MOS) group, which FI was higher than that of the control birds. lji et

Table 2 - Average weight gain (WG), feed intake (FI), feed conversion ratio (FCR), livability (L), and production efficiency index (PEI) of broilers supplemented with additives alternatives to antimicrobials.

\begin{tabular}{|c|c|c|c|c|c|c|c|c|}
\hline \multirow[t]{2}{*}{ Parameters } & \multicolumn{7}{|c|}{ Treatments } & \multirow[b]{2}{*}{$\mathrm{P}^{4}$} \\
\hline & Control & Antimicro ${ }^{1}$ & Probiotic & Prebiotic & Symbiotic & Org. Ac. ${ }^{2}$ & $\mathrm{CV}^{3}(\%)$ & \\
\hline \multicolumn{9}{|c|}{$1-10$ days of age } \\
\hline WG (g) & $209.85 \mathrm{~b}$ & $236.75 \mathrm{a}$ & $232.08 \mathrm{ab}$ & $225.50 \mathrm{ab}$ & $239.78 \mathrm{a}$ & $226.19 a b$ & 5.67 & 0.006 \\
\hline $\mathrm{Fl}(\mathrm{g})$ & 284.17 & 296.94 & 288.71 & 292.39 & 288.33 & 281.11 & 3.56 & 0.140 \\
\hline FCR $(g / g)$ & $1.37 \mathrm{~b}$ & $1.25 a$ & $1.24 \mathrm{a}$ & $1.29 \mathrm{ab}$ & $1.20 \mathrm{a}$ & $1.24 \mathrm{a}$ & 4.02 & $<0.001$ \\
\hline $\mathrm{L}(\%)$ & 98.89 & 100 & 98.89 & 100 & 100 & 100 & 0.99 & 0.107 \\
\hline \multicolumn{9}{|c|}{ 1-21 days of age } \\
\hline WG (g) & $874.14 b$ & $940.00 \mathrm{a}$ & $881.07 \mathrm{ab}$ & $900.08 \mathrm{ab}$ & $894.41 \mathrm{ab}$ & $891.99 a b$ & 3.88 & 0.043 \\
\hline $\mathrm{Fl}(\mathrm{g})^{\star}$ & $1277.93 \mathrm{c}$ & $1324.75 \mathrm{ab}$ & $1284.26 \mathrm{bc}$ & $1336.38 \mathrm{a}$ & $1290.18 b c$ & $1299.02 \mathrm{abc}$ & 2.59 & 0.029 \\
\hline FCR $(g / g)$ & 1.47 & 1.41 & 1.47 & 1.49 & 1.45 & 1.46 & 3.09 & 0.079 \\
\hline$L(\%)$ & 97.22 & 99.45 & 98.33 & 98.89 & 99.45 & 99.45 & 1.96 & 0.305 \\
\hline \multicolumn{9}{|c|}{$1-35$ days of age } \\
\hline WG (g) & 2234.26 & 2265.43 & 2228.34 & 2218.89 & 2218.52 & 2186.74 & 2.62 & 0.353 \\
\hline $\mathrm{Fl}(\mathrm{g})^{\star}$ & $3600.71 \mathrm{ab}$ & $3676.18 \mathrm{a}$ & $3602.47 \mathrm{ab}$ & $3676.68 a$ & $3590.88 \mathrm{~b}$ & $3669.58 \mathrm{ab}$ & 1.70 & 0.037 \\
\hline $\mathrm{FCR}(\mathrm{g} / \mathrm{g})$ & $1.63 \mathrm{a}$ & $1.64 \mathrm{a}$ & $1.64 a$ & $1.67 \mathrm{ab}$ & $1.65 \mathrm{ab}$ & $1.69 \mathrm{~b}$ & 1.72 & 0.003 \\
\hline $\mathrm{L}(\%)$ & 95.56 & 97.22 & 95.00 & 97.78 & 95.00 & 98.33 & 4.09 & 0.531 \\
\hline \multicolumn{9}{|c|}{$1-42$ days of age } \\
\hline WG (g) & 2848.79 & 2907.30 & 2825.04 & 2851.98 & 2849.25 & 2790.67 & 2.88 & 0.287 \\
\hline $\mathrm{Fl}(\mathrm{g})$ & 4955.27 & 5025.86 & 4947.55 & 5073.11 & 4941.55 & 5040.27 & 2.41 & 0.289 \\
\hline FCR $(\mathrm{g} / \mathrm{g})$ & $1.77 \mathrm{ab}$ & $1.75 \mathrm{a}$ & $1.80 \mathrm{ab}$ & $1.80 \mathrm{ab}$ & $1.77 \mathrm{ab}$ & $1.83 \mathrm{~b}$ & 2.01 & 0.011 \\
\hline$L(\%)$ & 92.78 & 95.00 & 90.55 & 95.00 & 92.78 & 97.22 & 5.36 & 0.295 \\
\hline PEI (\%) & 356.32 & 376.31 & 338.30 & 357.57 & 354.52 & 354.11 & 7.48 & 0.315 \\
\hline
\end{tabular}

Means followed by different letters in the same row are different by the test of Tukey $(p<0.05)$, except for * $F$ at 21 and 35 days of age), which are different by the test of Duncan $(p<0.05) .{ }^{1}$ Antimicrobial (enramycin). ${ }^{2}$ Organic acid. ${ }^{3}$ Coefficient of variation. ${ }^{4}$ Probability. 
al. (2001), studying the intestinal function and structure of MOS-supplemented broilers, reported that MOS promoted higher Fl, whereas Albino et al. (2006) and Oliveira et al. (2008 b) did not find any effects of this additive on broiler Fl. The broilers in the antimicrobial and prebiotic groups presented higher Fl between one and 35 days compared with the symbiotic group, but none of the treatments was different from the control.

During the pre-starter phase (1-10 days), the FCR of broiler chickens fed alternative additives (except for the prebiotic-fed birds) was similar to the FCR of the antimicrobial group and better $(p<0.05)$ than that of the control birds. These results are consistent with those of Paz et al. (2010) obtained during the same period (1-10 days), when evaluating the effects of probiotics and prebiotics on broiler performance. The applied treatments did not influence $(p>0.05)$ FCR during the period of 1-21 days of age. Recently, Ramos et al. (2011) also did not find any influence of probiotic, prebiotic, or symbiotic additives on the FCR of 21-d-old broilers.

During the period of 1-35 days of age, the probiotic, prebiotic, and symbiotic treatments promoted similar

Table 3 - Intestinal segment lengths of the experimental broilers at 42 days of age.

\begin{tabular}{|c|c|c|c|c|c|c|c|c|}
\hline \multirow{2}{*}{ Treatments } & \multicolumn{8}{|c|}{ Parameters (cm) } \\
\hline & Duodenum & Jejunum & Ileum & Cecum & Colon & TOTAL & $\mathrm{SI}^{5}$ & $\mathrm{LI}^{6}$ \\
\hline Control & 28.58 & 54.71 & 54.25 & 33.96 & 7.46 & 178.96 & 137.54 & 41.42 \\
\hline Antimicrob ${ }^{1}$ & 29.50 & 57.50 & 52.29 & 33.71 & 7.83 & 180.83 & 139.29 & 41.54 \\
\hline Probiotic & 31.54 & 59.33 & 55.25 & 33.92 & 8.08 & 188.12 & 146.12 & 42.00 \\
\hline Prebiotic & 30.58 & 56.87 & 56.08 & 33.92 & 7.79 & 185.25 & 143.54 & 41.71 \\
\hline Symbiotic & 30.00 & 58.92 & 55.79 & 33.58 & 7.87 & 186.17 & 144.71 & 41.46 \\
\hline Org. Ac. ${ }^{2}$ & 30.25 & 55.87 & 55.25 & 33.17 & 7.62 & 182.17 & 141.37 & 40.79 \\
\hline Mean & 30.08 & 57.20 & 54.82 & 33.71 & 7.78 & 183.58 & 142.10 & 41.49 \\
\hline $\mathrm{CV}^{3}(\%)$ & 10.32 & 13.07 & 11.50 & 11.15 & 10.28 & 8.02 & 9.56 & 9.33 \\
\hline $\mathrm{P}^{4}$ & 0.298 & 0.646 & 0.714 & 0.995 & 0.506 & 0.644 & 0.622 & 0.985 \\
\hline
\end{tabular}

${ }^{1}$ Antimicrobial; ${ }^{2}$ organic acid; ${ }^{3}$ coefficient of variation; ${ }^{4}$ probability; ${ }^{5}$ small intestine; ${ }^{6}$ large intestine.

Table 4 - Relative weight ${ }^{1}$ of the intestinal segments of the experimental broilers at 42 days of age.

\begin{tabular}{|c|c|c|c|c|c|c|c|c|}
\hline \multirow{2}{*}{ Treatments } & \multicolumn{8}{|c|}{ Parameters (\%) } \\
\hline & Duodenum & Jejunum & Ileum & Cecum & Colon & Total & $\mathrm{SI}^{6}$ & $\mathrm{LI}^{7}$ \\
\hline Control & 0.67 & $1.10 \mathrm{ab}$ & 0.96 & 0.62 & 0.17 & $3.51 \mathrm{ab}$ & $2.73 a b$ & 0.78 \\
\hline Antimicrob ${ }^{2}$ & 0.64 & $1.05 \mathrm{~b}$ & 0.92 & 0.57 & 0.14 & $3.32 \mathrm{~b}$ & $2.60 \mathrm{~b}$ & 0.71 \\
\hline Probiotic & 0.77 & $1.19 \mathrm{ab}$ & 1.08 & 0.69 & 0.16 & $3.90 \mathrm{a}$ & $3.05 \mathrm{a}$ & 0.85 \\
\hline Prebiotic & 0.71 & $1.24 \mathrm{a}$ & 1.10 & 0.61 & 0.15 & $3.81 \mathrm{a}$ & $3.05 \mathrm{a}$ & 0.76 \\
\hline Symbiotic & 0.68 & $1.15 \mathrm{ab}$ & 1.08 & 0.57 & 0.16 & $3.65 \mathrm{ab}$ & $2.91 \mathrm{ab}$ & 0.73 \\
\hline Org. Ac. ${ }^{3}$ & 0.69 & $1.14 a b$ & 1.01 & 0.60 & 0.16 & $3.59 a b$ & $2.84 a b$ & 0.75 \\
\hline Mean & 0.69 & 1.14 & 1.03 & 0.61 & 0.16 & 3.63 & 2.86 & 0.77 \\
\hline $\mathrm{CV}^{4}(\%)$ & 15.53 & 12.35 & 16.92 & 25.83 & 22.04 & 10.19 & 10.47 & 22.38 \\
\hline $\mathrm{p}^{5}$ & 0.063 & 0.029 & 0.055 & 0.490 & 0.440 & 0.004 & 0.002 & 0.476 \\
\hline
\end{tabular}

Means followed by different letters in the same column are different by the test of Tukey $(p<0.05) .1 \%$ relative to live weight; ${ }^{2}$ Antimicrobial; ${ }^{3}$ organic acid; ${ }^{4}$ coefficient of variation; ${ }^{5}$ probability; ${ }^{6}$ small intestine; ${ }^{7}$ large intestine.
FCR compared with the antimicrobial treatment, and they were not different from the control treatment. The diet with organic acid resulted in worse FCR $(p<0.05)$ compared with the control treatment. On the other hand, Viola \& Vieira (2007), and Chowdhury et al. (2009) reported better FCR in broilers fed organic acids relative to the control diet between one and 35 days of age.

During the total period experimental period (1-42 days), the treatments containing alternative additives, except for organic acid, promoted similar FCR compared with the antimicrobial treatment; however, none of the treatments was different from the control group. These results are different from those reported by Maiorka et al. (2001), who worked with a probiotic, a prebiotic, and a symbiotic, and by Khosravi et al. (2010), who worked with organic acids, and observed better feed conversion ratio in broilers fed alternative additives compared with the control birds during the entire experimental period. Livability, and production efficiency were not affected ( $p>0.05$ ) by the treatments in the present study.

Although in the current experiment birds were exposed to a natural health challenge by means of reused litter from a commercial broiler flock, performance improved when growth promoter additives were added to the diet compared to the control group during the prestarter and starter phases. However, considering the total rearing period, performance parameters did not improve.

There was no influence of the treatments on intestine length of 42-d-old broiler chickens (Table 3).

On the other hand, intestinal segment relative weights were significantly affected by the treatments $(p<0.05)$. Jejunum, small intestine, and total intestine relative weights were statistically lower in the birds fed the antimicrobial agent compared with those fed the diets containing the probiotic and the prebiotic products (Table 4). 
Antimicrobial treatments affect both pathogenic and beneficial microorganisms, reducing general bacterial population (Anderson et al., 1999). This mode of action on intestinal microbes may impair microbial fermentation and short-chain fatty acid production, which supply the energy required for enterocyte development (Lin \& Visek, 1991). Therefore, according to Costa et al. (2007), reduced production of volatile fatty acids may result in lower cell replication in the intestinal epithelium of broiler chickens fed antimicrobials, with consequent reduction in relative intestinal weight. Different results were described by Boratto et al. (2004), who did not find any influence of probiotics, homeopathic products, or antibiotics on total intestinal relative weight of 42-d-old broiler chickens infected or not with Escherichia coli.

No influence of the applied treatments was observed on the morphometrics of different layers of the gut wall (mucosa, submucosa, internal circular and external longitudinal muscle layers) in none of the analyzed small intestine segments (Table 5). However, Pelicano et al. (2003), Pelicano et al. (2007), Oliveira et al. (2009), and Panda et al. (2009) observed positive effects of additives alternative to antimicrobial growth enhancers on the small intestine mucosa morphometrics, considering villi height and crypt depth of 42-d-old broilers.
Considering the morphometrics of the cecum layers, broilers fed the diet with prebiotic (MOS) presented thicker $(p<0.05)$ external longitudinal muscle layer compared with the control group (Table 6 and Figure 1). Oliveira et al. (2008a), in a study on the effects of MOS and an enzyme complex on the morphometrics of the small intestine of broiler chickens, also observed thickening of the external longitudinal muscle layer. Those authors suggest that the higher short-chain fatty acid fermentation and production promoted by MOS addition to the diet may stimulate the activity of muscle layer, which is responsible for intestinal peristalsis.

Intestinal mucosa integrity, considering especifically epithelial loss, mucus presence, and villi organization of the duodenum, jejunum, ileum, and cecum, was not influenced by the treatments. When the segment of the large intestine (cecum) was evaluated under light and scanning electron microscopy, no villi were detected; only crypts were present in the collected portion (intermediate portion of the right cecum). In addition to the crypts, this portion also presented circular folds, which form Kerckring valves that are projections of the mucosa and part of the submucosa (Figures 2 and 3). According to Boleli et al. (2002), cecal villus size is reduced from the base to the most distal point, the tip. Therefore, most of the cecal mucosa consists of long, simple, non-branched tubular glands called Lieberkühn glands or crypts.

Table 5 - Thickness $(\mu \mathrm{m})$ of the different layers of the small intestine and cecum of 42 -d-old of the experimental broilers.

\begin{tabular}{|c|c|c|c|c|c|c|c|}
\hline \multirow{2}{*}{ Parameters $(\mu \mathrm{m})$} & \multicolumn{7}{|c|}{ Treatments } \\
\hline & Control & Antimicrob ${ }^{1}$ & Probiotic & Prebiotic & Symbiotic & Org. Ac. ${ }^{2}$ & $\mathrm{CV}^{3}(\%)$ \\
\hline \multicolumn{8}{|c|}{ Duodenum } \\
\hline Mucosa & 2128.97 & 2138.28 & 2250.84 & 2266.60 & 2278.46 & 2270.32 & 12.14 \\
\hline Submucosa & 31.49 & 35.72 & 30.39 & 33.47 & 30.46 & 29.64 & 26.53 \\
\hline Internal m. & 241.89 & 276.68 & 240.19 & 237.67 & 271.26 & 242.91 & 24.68 \\
\hline External m. & 83.90 & 89.31 & 73.26 & 87.43 & 87.10 & 90.51 & 31.99 \\
\hline \multicolumn{8}{|c|}{ Jejunum } \\
\hline Mucosa & 1928.69 & 2026.91 & 1892.92 & 2059.91 & 2004.80 & 2070.36 & 11.76 \\
\hline Submucosa & 27.69 & 22.65 & 22.10 & 20.82 & 20.36 & 19.88 & 28.05 \\
\hline Internal m. & 279.68 & 258.04 & 296.06 & 296.64 & 266.78 & 274.48 & 21.40 \\
\hline External m. & 88.47 & 76.95 & 81.48 & 93.42 & 81.91 & 89.61 & 28.38 \\
\hline \multicolumn{8}{|c|}{ Ileum } \\
\hline Mucosa & 1372.76 & 1459.13 & 1354.28 & 1471.27 & 1395.44 & 1477.17 & 13.15 \\
\hline Submucosa & 25.68 & 28.57 & 26.53 & 25.71 & 25.78 & 21.28 & 21.26 \\
\hline Internal m. & 321.49 & 341.49 & 346.51 & 348.74 & 337.32 & 330.21 & 20.83 \\
\hline External m. & 111.62 & 112.47 & 107.93 & 133.09 & 110.97 & 109.70 & 21.04 \\
\hline \multicolumn{8}{|c|}{ Cecum } \\
\hline Mucosa & 346.97 & 373.87 & 370.68 & 355.99 & 375.53 & 365.72 & 15.23 \\
\hline Submucosa & 26.78 & 26.78 & 28.48 & 25.47 & 24.57 & 23.98 & 21.09 \\
\hline Internal m. & 452.09 & 490.90 & 494.86 & 543.11 & 483.80 & 484.31 & 20.17 \\
\hline External $\mathrm{m}$. & $85.68 b$ & $84.53 \mathrm{~b}$ & $95.55 \mathrm{ab}$ & $120.44 \mathrm{a}$ & $91.24 \mathrm{~b}$ & $98.01 \mathrm{ab}$ & 22.31 \\
\hline
\end{tabular}

Means followed by different letters in the same row are statistically different by the test of Tukey $(\mathrm{p}<0.05) .{ }^{1}$ Antimicrobial; ${ }^{2}$ organic acid; ${ }^{3}$ coefficient of variation; $\mathrm{M}=$ muscle layer. 
Fernandes BCS, Martins MRFB, Mendes AA, Milbradt EL, Sanfelice C, Martins BB, Aguiar EF, Bresne C

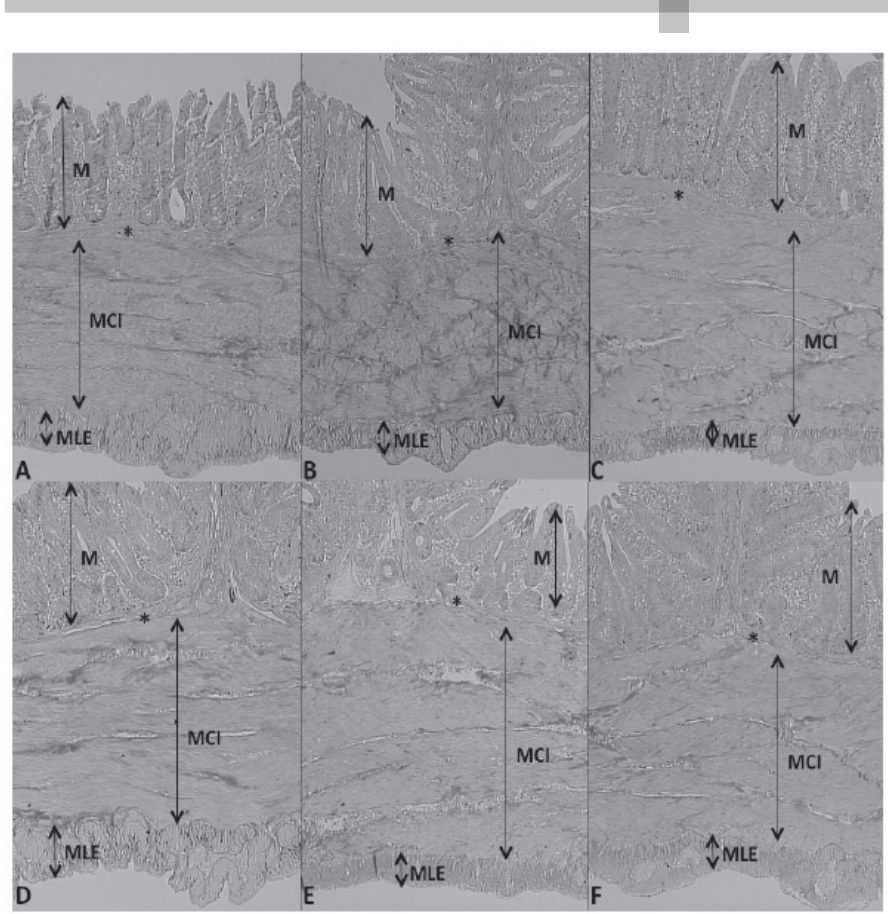

Figure 1 - Photomicrography of the cecal wall of 42-d-old broiler chickens. In A: control treatment; B: antimicrobial; C: probiotic; D: prebiotic; E: symbiotic, and F: organic acid. Layers: mucosa (M); submucosa $\left({ }^{*}\right)$; internal circular muscular (MCI); external longitudinal muscular (MLE). Masson trichrome stain, 10x.

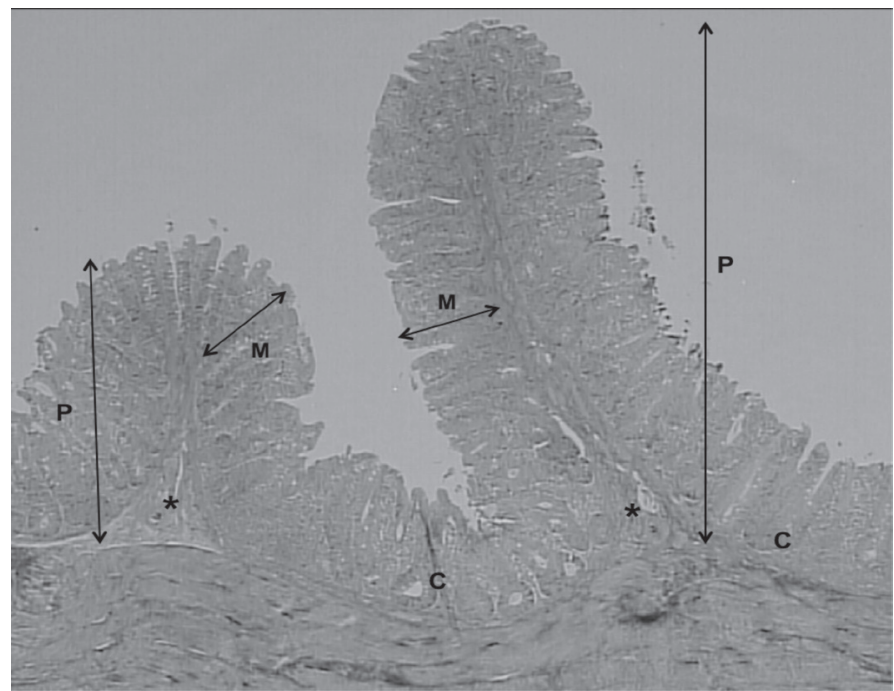

Figure 2 - Photomicrography of the intermediate portion of the cecum of 42 - $d$-old broiler chickens. Note that the mucosa layer $(\mathrm{M})$ presents only crypts $(\mathrm{C})$ and the presence of folds $(P)$, which are projection of part of the mucosa and submucosa layer $\left({ }^{*}\right)$. Masson trichrome stain, $5 x$

\section{CONCLUSIONS}

The probiotic, prebiotic, symbiotic and organic acid additives evaluated improved broiler performance during the beginning of the rearing period. However, during the total rearing period and under the conditions of the present experiment, the tested additives did not influence broiler performance or intestinal integrity.

\section{Intestinal Integrity and Performance of Broiler Chickens Fed A Probiotic, A Prebiotic, or an Organic Acid}

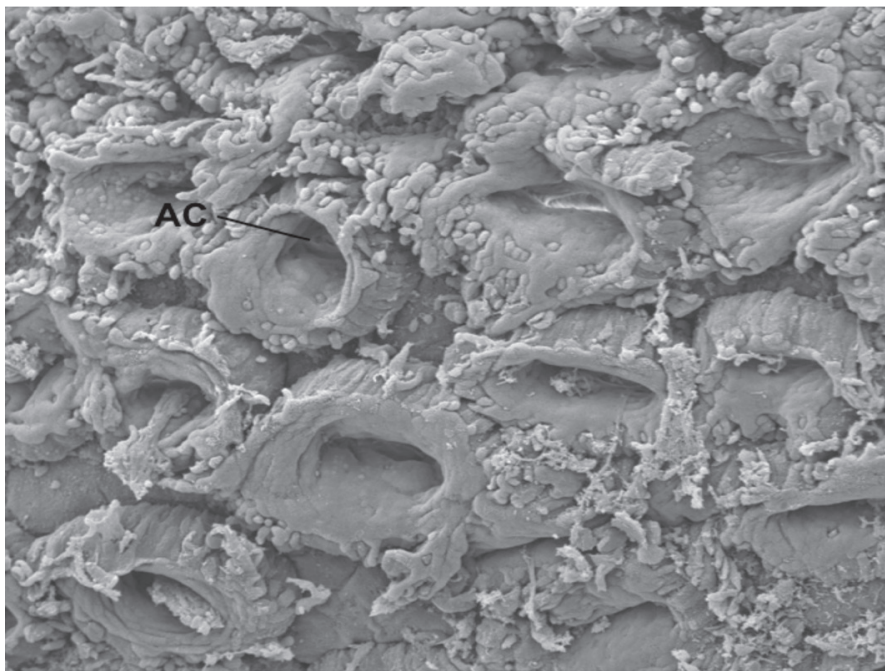

Figure 3 - Scanning electron micrograph of the surface of the mucosa of the interme diate portion of the cecum of 42-d-old broiler chickens. Note an opened crypt (AC), 800x.

\section{ACKNOWLEDGEMENTS}

The authors thank Fundação de Amparo à Pesquisa do Estado de São Paulo (FAPESP) for funding this study and the scholarship.

\section{REFERENCES}

Anderson DB, McCracken VJ, Aminov RI, Simpson JM, Mackie RI, Verstegen MW A, Gaskins HR. Gut microbiology and growth-promoting antibiotics in swine. Pigs News Information 1999;20:115-122.

Albino LFT, Feres FA, Dionizio MA, Rostagno HA, Júnior JGV, Carvalho DCO, Gomes PC, Costa CHR. Uso de prebióticos à base de mananoligossacarídeo em rações para frangos de corte. Revista Brasileira de Zootecnia 2006;35(3):742-749.

Appelt MDA, Nunes RV, Pozza PC, Silva WTM, Venturi I, Nunes CGV. Níveis de probiótico em rações de origem animal e vegetal para frangos de corte. Revista Brasileira de Zootecnia 2010;39(4):765-771.

Behmer AO, Tolosa EMC, Freitas Neto AG. Manual de técnicas para histologia normal e patológica. $2^{a}$ ed. Barueri: Editora Manole; 2003. $331 p$.

Bellaver C, Scheuermann G. Aplicações dos ácidos orgânicos na produção de aves de corte. Anais da Conferência AVESUI; 2004; Florianópolis, Santa Catarina. Brasil. Itu: Gessulli; 2004. p.1-16.

Boleli IC, Maiorka A, Macari M. Estrutura funcional do trato digestório. In Macari M, Furlan RL, Gonzales E. Fisiologia aviária aplicada a frangos de corte. Jaboticabal: Funep; 2002. cap.5, p.75-95

Boratto AJ, Lopes DC, Oliveira RFM, Albino LFT, Sá LM, Oliveira GA. Uso de antibiótico, de probiótico e de homeopatia em frangos de corte criados em ambiente de conforto, inoculados ou não com Escherichia coli. Revista Brasileira de Zootecnia 2004;33(6):1477-1485

Chowdhury R, Islam KMS, Khan MJ, Karim MR, Haque MN, Khatun M, Pesti GM. Effect of citric acid, avilamycin, and their combination on the performance, tibia ash, and immune status of broilers. Poultry Science 2009;88(8):1616-1622

Costa LB, Tse MLP, Miyada VS. Extratos vegetais como alternativas aos antimicrobianos promotores de crescimento para leitões recémdesmamados. Revista Brasileira de Zootecnia 2007;36(3):589-595. 
Edens FW. An alternative for antibiotic se in poultry: probiotics. Revista Brasileira de Ciência Avícola 2003;5(2):75-97.

Godoi MJS, Albino LFT, Rostagno HS, Gomes PC, Barreto SLT, Vargas Junior JG. Utilização de aditivos em rações formuladas com milho normal e de baixa qualidade para frangos de corte. Revista Brasileira de Zootecnia 2008;37(6):1005-1011.

lii PA, Saki AA, Tivey DR. Intestinal structure and function of broiler chickens on diets supplemented with a mannan oligosaccharide. Journal of the Science of Food and Agriculture 2001;81(12):1186-1192.

Khosravi A, Boldaji F, Dastar B, Hasani S. Immune response and performance of broiler chicks fed protexin and propionic acid. International Journal of Poultry Science 2010;9(2):188-191.

Lin HC, Visek WJ. Colon mucosal cell damage by ammonia in rats. Journal of Nutrition 1991;121:887-893.

Maiorka A, Santin E, Sugeta SM, Almeida JG, Macari M. Utilização de prebióticos, probióticos ou simbióticos em dieta para frangos. Revista Brasileira de Ciência Avícola 2001;3(1):75-82.

Meurer RFP, Leal PC, Rocha C, Bueno IJM, Maiorka A, Dahlke F. Evaluation of the use of probiotics in diets with or without growth promoters for broiler chicks. Revista Brasileira de Zootecnia 2010;39(12):2687-2690.

Oliveira MC, Cancherini LC, Marques RH, Gravena RA, Moraes VMB. Mananoligossacarídeos e complexo enzimático em dietas para frangos de corte. Revista Brasileira de Zootecnia 2009;38(5):879-886.

Oliveira MC, Marques RH, Gravena RA, Moraes VMB. Morfometria do intestino delgado de frangos tratados com dietas adicionadas de mananoligossacarídeo e complexo enzimático. Revista Biotemas 2008 a;21(3):135-142

Oliveira MC, Rodrigues EA, Marques RH, Gravena RA, Guandolini GC, Moraes VMB. Performance and morphology of intestinal mucosa of broilers fed mannan-oligosaccharides and enzymes. Arquivos Brasileiros de Medicina Veterinária e Zootecnia 2008 b;60(2):442-448.

Panda AK, Rao SVR, Raju MVLN, Sunder GS. Effect of butyric acid on performance, gastrointestinal tract health and carcass characteristics in broiler chickens. Assian-Australasian Journal Animal Science 2009; 7:1026-1031.

Paz AS, Abreu RD, Costa MCMM, Jaeger SMPL, Rocha AP, Ferreira BP, Santana RS Campos BM. Aditivos promotores de crescimento na alimentação de frangos de corte. Revista Brasileira de Saúde e Produção Animal 2010;11(2):395-402
Pelicano ERL, Souza PA, Souza HBA, Oba A, Norkus EA, Kodawara LM, Lima TMA. Morfometria e ultra-estrutura da mucosa intestinal de frangos de corte alimentados com dietas contendo diferentes probióticos. Revista Portuguesa de Ciências Veterinárias 2003;98(547):125-134.

Pelicano ERL, Souza PA, Souza HBA, Figueiredo DF, Amaral CMC. Morphometry and ultra-structure of the intestinal mucosa of broilers feed different additives. Brazilian Journal of Poultry Science 2007;9(3):173-180

Ramos LSN, Lopes JB, Silva SMMS, Silva FES, Ribeiro MN. Desempenho e histomorfometria intestinal de frangos de corte de 1 a 21 dias de idade recebendo melhoradores de crescimento. Revista Brasileira de Zootecnia 2011;40(8):1738-1744

Rostagno HS, Albino LFT, Donzele JL, Gomes PC, Oliveira RF, Lopes DC, Ferreira AS, Barreto SLT. Tabelas brasileiras para aves e suínos: composição de alimentos e exigências nutricionais. 2.ed. Viçosa: UFV Departamento de Zootecnia; 2005. 186p.

Salazar PCR, Albuquerque R, Takeara P, Trindade Neto MA, Araújo LF. Efeito dos ácidos lático e butírico, isolados e associados, sobre o desempenho e morfometria intestinal em frangos de corte. Brazilian Journal of Veterinary Research and Animal Science 2008;45(6):463-471.

Santos JRG, Turnes CG. Probióticos em avicultura. Ciência Rura 2005;35(3):741-747.

Silva LP, Nörnberg JL. Prebióticos na nutrição de não ruminantes. Ciência Rural 2003;33(5):983-990.

Van Leeuwen P, Mouwen JMV, Van Der Klis JD, Verstegen MW. Morphology of de small intestinal mucosal surface of broilers in relation to age, diet formulation, small intestinal microflora and performance. British Poultry Science 2004;45:41-48.

Viola ES, Vieira SL. Suplementação de acidificantes orgânicos e inorgânicos em dietas para frangos de corte: desempenho zootécnico e morfologia intestinal. Revista Brasileira de Zootecnia 2007;36(4):1097-1104.

Viola ES, Vieira SL, Torres CA, Freitas DM, Berres J. Desempenho de frangos de corte sob suplementação com ácidos lático, fórmico, acético e fosfórico no alimento ou na água. Revista Brasileira de Zootecnia 2008:37(2):296-302

Yamauchi K, Isshiki Y. Scanning electron microscopic observations on the intestinal villi in growing white leghorn and broiler chickens from 1 to 30 days of age. British Poultry Science 1991;32(1):67-78 